\title{
Aktivitas Antibakteri Ekstrak Etanol Daun Bandotan (Ageratum Conyzoides Lin) Terhadap Escherichia Coli, Propionibacterium Acnes, dan Streptococcus Sobrinus
}

\author{
Farida Aryani* \\ Teknologi Hasil Perkebunan, \\ Politeknik Pertanian Negeri \\ Samarinda,75242 \\ ary_ani02@yahoo.com \\ *Corresponding author \\ Misnah Wati \\ Pengelolaan Hasil Hutan, \\ Politeknik Pertanian Negeri \\ Samarinda,75242 \\ misnawati.thh@gmail.com
}

\author{
Wartomo \\ Pengelolaan Hasil Hutan, \\ Politeknik Pertanian Negeri \\ Samarinda, 75242 \\ wartomo63.phh@gmail.com
}

\author{
Fikri Hernandi \\ Pengelolaan Hasil Hutan, \\ Politeknik Pertanian Negeri \\ Samarinda,75242 \\ fhernandi271170@gmail.com
}

\author{
Nur Maulida Sari \\ Pengelolaan Hasil Hutan, \\ Politeknik Pertanian Negeri \\ Samarinda,75242 \\ nurmaulidasr@politanisamarinda.ac. \\ id \\ Erna Rositah \\ Pengelolaan Hutan \\ Politeknik Pertanian Negeri \\ Samarinda, 75242 \\ rnarositah7@gmail.com
}

\begin{abstract}
Abstrak-Daun bandotan (Ageratum conyzoides Lin) merupakan salah satu tanaman yang digunakan sebagai obat tradisional daun bandotan mempunyai berbagai khasiat, salah satunya sebagai antibakteri Tujuan penelitian ini adalah mengetahui efek antibakteri ekstrak daun bandotan terhadap pertumbuhan bakteri Propionumbacterium acnes, Escherichia coli, dan Streptococcus mutan. Simplisia daun bandotan diekstrak menggunakan etanol pada suhu kamar, kemudian dilakukan pemekatan ekstrak menggunakan vacuum rotary evaporator sehingga diperoleh ekstrak kasar. Analisis fitokimia dilakukan untuk mengidentifikasi golongan senyawa metabolit sekunder yang meliputi flavonoid, alkaloid, tanin, saponin terpenoid dan steroid. Pengujian aktivitas antibakteri menggunakan metode difusi sumuran dengan konsentrasi 100, 200, 400, dan $600 \mu \mathrm{g} /$ well untuk mengetahui Konsentrasi Hambat Minimum. Chlorampenicol digunakan sebagai kontrol positif dan aseton sebagai kontrol negatif. Hasil penelitian dinyatakan bahwa ekstrak daun bandotan mengandung senyawa metabolit sekunder yaitu flavonoid, saponin, tannin, dan steroid. Sedang alkaloid dan terpenoid tidak terdeteksi. Hasil pengujian aktivitas antibakteri eksrak etanol daun bandotan berpotensi sebagai bahan antibakteri dengan KHM pada E.coli antara100-200 $\mu \mathrm{g} / \mathrm{well}$ dan pada $P$. acne dan S. Sobrinus di bawah $100 \mu \mathrm{g} / \mathrm{well}$.
\end{abstract}

Kata Kunci-Bandotan, Ageratum conyzoides, antibakteri, Propionumbacterium acnes, Escherichia coli, dan Streptococcus mutan

\section{PENDAHULUAN}

Indonesia merupakan negara dengan sumber daya alam yang berlimpah diantaranya yaitu beraneka ragam flora dan fauna yang berada di Indonesia, yang memiliki lebih dari 30.000 spesies tumbuhan asli Indonesia, 96.000 spesies sudah diketahui manfaatnya sebagai obat dan sebagainya telah digunakan sebagai obat tradisional (Deasywati, 2011).

Bakteri merupakan mikroorganisme prokariotik yang dapat memberikan dampak positif bagi kesehatan, tetapi dapat juga memberikan dampak negatif dengan menimbulkan penyakit atau bersifat patogen (Kumar dan Chordia, 2017). Obat yang banyak digunakan untuk menghambat/membunuh bakteri patogen yang menginfeksi manusia sebagian besar berupa antibiotik sintetik yang memiliki risiko resisten sehingga menyebabkan gagalnya pengobatan sehingga pasien menjadi terinfeksi dalam waktu yang lama memicu terjadinya resistensi antibiotik sintetik terhadap bakteri pathogen. Keadaan ini membutuhkan solusi untuk mencari obat alternatif yang aman, murah, mudah diperoleh dan lebih baik sebagai obat baru pengganti antibiotik sintetik. Senyawa bahan antibakteri tersebut salah satunya dapat diperoleh dari tumbuh-tumbuhan (Kurniawan, dkk. 2019)

Bandotan (Ageratum conyzoides L.) merupakan tumbuhan liar yang mudah didapat di Indonesia dan lebih dikenal sebagai tumbuhan pengganggu (gulma) di kebun dan ladang. Bandotan ini secara empiris diketahui mempunyai khasiat sebagai bahan obat dan telah digunakan di beberapa daerah. Bandotan banyak dimanfaatkan sebagai obat luka baru, luka berdarah, sariawan ,radang tenggorokan, radang telinga, rematik, 
keseleo, pendarahan rahim, , tumorrahim, malaria, perut kembung, mulas, muntah, diare dan mengobati penyakit yang disebabkan oleh infeksi bakteri (Mengkido, dkk. 2019). Tujuan dari penelitian ini adalah untuk mengetahui aktivitas antibakteri pada ekstrak etanol daun bandotan terhadap bakteri Escherichia coli, Propionibacterium acnes, dan Streptococcus sobrinus.

\section{STUDI PUSTAKA}

Antibakteri adalah bahan atau senyawa yang dapat membasmi bakteri terutama bakteri pathogen. Senyawa antibakteri harus mempunyai sifat toksisitas selektif, yaitu berbahaya bagi parasite tetapi tidak berbahaya bagi inangnya (Xia et al., 2010).

Mekanisme penghambatan terhadap pertumbuhan bakteri oleh senyawa antibakteri dapat berupa perusakan dinding sel dengan cara menghambat pembentukannya atau mengubahnya setelah selesai terbentuk, perubahan permeabilitas membran sitoplasma sehingga menyebabkan keluarnya bahan makanan dari dalam sel, perubahan molekul protein dan asam nukleat, penghambatan kerja enzim, dan penghambatan sintesis asam nukleat dan protein. Di bidang farmasi, bahan antibakteri dikenal dengan nama antibiotik, yaitu suatu substansi kimia yang dihasilkan oleh mikroba dan dapat menghambat pertumbuhan mikroba lain sintesisi dinding sel, menghambat sintesis protein, mengubah fungsi membrane plasma, dan menghambat sintesis asam nukleat (Waluyo 2010).

\section{METODE}

\section{A. Material}

Jenis tumbuhan yang diteliti adalah jenis Bandotan (Ageratum conyzoides Lin). Daun Bandotan diambil di Desa Surya, Kecamatan Loa Duri Ulu, Kabupaten Kutai Kartanegara. Bahan kimia yang digunakan adalah media Nutrient Broth, agar, glukosa, bakteri Escherichia coli, Propionibacterium acnes, dan Streptococcus sobrinus, asam klorida $2 \mathrm{~N}$, pereaksi mayer, pereaksi bouchardat, pereaksi dragendorf, $\mathrm{HCl}$ pekat, etanol, aquades, aseton, $\mathrm{Pb}$ asetat, $\mathrm{NaOH}, \mathrm{CH}_{3} \mathrm{COOH}$, Chlorampenicol, kertas saring, aluminium foil, kapas swaab.

Peralatan yang digunakan dalam penelitian ini adalah spektrofotometer, laminar air flow, timbangan analitik, autoclave, pinset, tabung reaksi, erlenmeyer, cawan petri, dan lemari asam.

\section{B. Pembuatan Simplisia}

Daun bandotan dicuci dengan air bersih untuk menghilangkan kotoran-kotoran yang menempel pada bahan baku. Kemudian bahan baku dikeringkan di tempat terlindung dari sinar matahari. Bahan baku yang telah dikeringkan dirajang-rajang menjadi serpihan kecil lalu dilakukan pengecilan ukuran dengan menggunakan blender.

\section{Menghitung MF (Moisture Factor)}

Bahan baku yang telah dijadikan serbuk, ditimbang sebanyak 2 gram. Kemudian dioven selama 24 jam. Setelah dioven, kemudian dimasukkan dalam desikator selama 15 menit, kemudian ditimbang.

$$
M F=\frac{B K T}{B N U}
$$

Keterangan $: \mathrm{MF}=$ moisture factor, $\mathrm{BKU}=$ berat kering udara $(\mathrm{g}), \mathrm{BKT}=$ berat kering tanur $(\mathrm{g})$

\section{Pembuatan Ekstrak Kasar}

Ekstrak daun bandotan dibuat dengan metode maserasi. Serbuk simplisia daun bandotan dimaserasi dengan cara direndam dengan pelarut etanol $95 \%$ sampai terendam seluruhnya dengan perbandingan antara simplisia dan pelarut adalah 1:10 selama 48 jam pada suhu kamar. Selanjutnya dilakukan penyaringan menggunakan kertas saring untuk memisahkan ekstrak dengan bahan tumbuhan. Hasil ekstrak kemudian dipekatkan dengan menggunakan rotary vacuum evaporator pada suhu $40^{\circ} \mathrm{C}$, sehingga diperoleh ekstrak kasar. Ekstrak kasar yang diproleh kemudian ditimbang dan perhitungan rendemen ekstrak diketahui dengan rumus :

$$
\text { Rendemen ekstrak }(\%)=\frac{\text { Berat ekstrak }}{\text { Berat samplexMF }} \times 100 \%
$$

\section{E. Pengujian Fitokimia}

Pengujian fitokimia dilakukan dengan uji perubahan warna yang mengaju pada Harborne (1987) dan Kokate (2001) untuk menguji adanya senyawa aktif yang meliputi :

1. Pengujian alkaloid (Kokate, 2001)

Identifikasi dilakukan dengan menggunakan larutan Dragendorff. Sebanyak $5 \mathrm{ml}$ ekstrak ditambahkan $2 \mathrm{ml}$ HCI, kemudian dimasukkan $1 \mathrm{ml}$ larutan Dragendorff. Perubahan warna larutan menjadi jingga atau merah mengindikasikan bahwa ekstrak mengandung alkaloid.

2. Pengujian flavonoid (Kakote, 2001)

Sebanyak $1 \mathrm{ml}$ ekstrak tumbuhan diberikan beberapa tetes natrium hidroksida encer $(\mathrm{NaOH} 1 \%)$ terbentuknya warna kuning yang jelas pada larutan ekstrak dan menjadi tidak berwarna setelah penambahan asam encer (HCI 1 \%) mengindikasikan adanya flavonoid.

3. Pengujian saponin (Harborne, 1987)

Pengujian dilakukan dengan memasukkan $10 \mathrm{ml}$ air panas kedalam tabung reaksi yang beisi $1 \mathrm{ml}$ sampel uji yang telah dilarutkan dalam aseton. Selanjutnya larutan didinginkan dan dikocok selama 10 detik. Terbentuknya buih selama kurang lebih selama 10 menit dengan ketinggian 1-10 cm dan tidak hilang bila ditambahkan 1 tetes HCI $2 \mathrm{~N}$ menandakan bahwa ekstrak yang diuji mengandung saponin.

4. Pengujian tanin (Kakote, 2001)

Sebanyak $10 \mathrm{ml}$ larutan ekstrak dimasukkan kedalam tabung reaksi dan ditambahkan larutan timbal asetat 
(CH3COO) $2 \mathrm{~Pb} 1 \%$. Positif tannin apabila pada reaksi terbentuk endapan kuning.

5. Pengujian triterpenoid dan steroid (Harborne, 1987)

Pengujian dilakukan dengan mencampur asam asetat ahidrid dan asam sulfat pekat yang biasa dikenal pereaksi Liebermann-Burchard. 10 tetes asam asetat ahidrid dan 2 tetes asam sulfat pekat ditambahkan secara berurutan kedalam $1 \mathrm{ml}$ sampel uji yang telah dilarutkan dalam aseton. Reaksi yang terjadi diikuti dengan perubahan warna, apabila terlihat terlihat warna hijau dan biru maka uji dinyatakan positif streroid, warna merah dan ungu maka uji dinyatakan positif untuk terpenoid.

\section{F. Uji Aktifitas Antibakteri}

1. Pembuatan media agar miring.

Nutrient Broth ditimbang sebanyak $1.3 \mathrm{~g}$, agar $2 \mathrm{~g}$ dan $1 \mathrm{~g}$ glukosa, kemudian dilarutkan dalam $100 \mathrm{~mL}$ aquadest menggunakan beaker glass. Setelah itu dipanaskan di atas hotplate sambil diaduk sampai mendidih. Sebanyak 15 $\mathrm{mL}$ dituangkan masing-masing pada tabung reaksi dan ditutup dengan kapas. Media tersebut disterilkan dalam autoklaf pada suhu $121^{\circ} \mathrm{C}$ selama 15 menit, kemudian didinginkan dalam laminar flow pada suhu ruangan selama 20 menit sampai media memadat pada kemiringan $30^{\circ}$. Media agar miring digunakan untuk inokulasi bakteri.

2. Kultur bakteri pada media

Bakteri uji diambil dengan jarum ose steril, lalu ditanamkan pada media agar miring dengan cara menggores. Selanjutnya diinkubasi dalam inkubator pada suhu $37^{\circ} \mathrm{C}$ selama 24 jam.

3. Pembuatan media Nutrient Agar (NA)

Ditimbang sebanyak 6,5 g Nutrient Broth, $10 \mathrm{~g}$ agar dan 5 g glukosa, kemudian dilarutkan dengan $500 \mathrm{~mL}$ aquadest dalam beaker glass. Setelah itu dipanaskan di atas hotplate sambil diaduk sampai mendidih kemudian disterilkan di dalam autoklaf pada suhu $121^{\circ} \mathrm{C}$ selama 15 menit. Sebanyak $20 \mathrm{~mL}$ media NA dalam keadaan panas dituang ke dalam cawan petri dengan tiga kali pengulangan. Pembuatan Suspensi Bakteri Propionibacterium acnes Koloni bakteri uji yang telah diremajakan diambil dengan jarum ose lalu dimasukkan ke dalam beaker glass yang telah diisi dengan aquadest steril. Pengenceran dibuat dan diukur kekeruhan dari suspensi dengan UV-Visibel spektrofotometer pada panjang gelombang $600 \mathrm{~nm}$ sampai diperoleh suspensi bakteri dengan nilai transmitan 70-75\%. Diambil suspensi bakteri Propionibacterium acne sebanyak $100 \mu \mathrm{L}$ menggunakan mikropipet dan diletakkan diatas media NA pada cawan petri kemudian diswab menggunakan kapas swaab steril. Uji aktivitas antibakteri dengan metode difusi (sumuran) dengan cara membuat lubang pada media. Masing-masing lubang sumuran diisi ekstrak dengan variasi konsentrasi $100 \mu \mathrm{g} / \mathrm{well}, 200 \mu \mathrm{g} / \mathrm{well}$, $300 \mu \mathrm{g} / \mathrm{well}, 600 \mu \mathrm{g} / \mathrm{well}$, chloramphenicol digunakan sebagai kontrol positif dan aceton sebagai kontrol negatif. Selanjutnya diinkubasi pada suhu $37^{\circ} \mathrm{C}$ selama 24 jam, lalu diukur diameter daya hambat $(\mathrm{mm})$ masing-masing sampel.

\section{HASIL DAN PEMBAHASAN}

\section{A. Rendemen Ekstrak}

Penelitian ini menggunakan metode maserasi satu tahap dengan pelarut organik Metode maserasi dipilih karena dapat mengekstraksi senyawa aktif dengan baik melalui perendaman tanpa pemanasan sehingga dapat menghindari kerusakan komponen senyawa yang labil dan tidak tahan panas (Syamsul dkk, 2020). Adanya sistem perendaman ini maka pelarut akan menembus dinding sel dan masuk ke dalam sel yang mengandung zat aktif. Maka zat aktif yang terdapat dalam sel akan larut dalam pelarut (Khoiriyah, 2014). Pelarut etanol digunakan karena etanol merupakan pelarut yang mampu mengikat semua komponen kimia yang terdapat pada tumbuhan bahan alam, baik yang bersifat non polar, semi polar, dan polar. Etanol adalah pelarut yang bersifat universal, merupakan cairan penyari yang mudah masuk kedalam sel melewati dinding sel bahan, sehingga metabolit sekunder yang terdapat dalam sitoplasma akan terlarut dalam pelarut dan senyawa akan terekstraksi sempurna (Hidayah,dkk.2016). Rendemen dari ekstrak kasar daun bandotan disajikan pada Tabel 1.

Tabel 1. Rendemen Ekstrak Daun Bandotan

\begin{tabular}{cccc}
\hline $\begin{array}{c}\text { Berat Sampel } \\
(\mathrm{g})\end{array}$ & $\begin{array}{c}\text { Moisture } \\
\text { Factor }\end{array}$ & $\begin{array}{c}\text { Berat Ekstrak } \\
(\mathrm{g})\end{array}$ & $\begin{array}{c}\text { Rendemen Ekstrak } \\
(\%)\end{array}$ \\
\hline 100 & 0,8449 & 8,6799 & 7,3336 \\
\hline
\end{tabular}

\section{B. Skrining Fitokimia}

Hasil pengujian fitokimia dapat diketahui beberapa kandungan yang ada pada ekstrak daun bandotan dan dapat dilihat pada tabel berikut.

Tabel 2. Kandungan Fitokimia Ekstrak Daun Bandotan

\begin{tabular}{ccc}
\hline Uji Fitokimia & Pereaksi & Hasil \\
\hline Alkaloid & Meyer & - \\
Flavonoid & $\mathrm{NaOH}$ Encer dan HCl Encer & + \\
Saponin & Akuadest Panas & + \\
Tanin & Pb Asetat & + \\
Terpenoid & Liebermann-Burchard & - \\
Steroid & Liebermann-Burchard & + \\
\hline
\end{tabular}

Keterangan $:+=$ Terdeteksi, $-=$ Tidak Terdeteksi

Uji fitokimia dilakukan untuk mendeteksi senyawa metabolit sekunder pada tumbuhan berdasarkan golongannya sebagai informasi awal dalam mengetahui aktivitas biologi dari suatu tumbuhan. Hasil yang diperoleh seperti terlihat pada tabel di atas menunjukkan bahwa daun Bandotan memiliki potensi fitokimia yang baik. Berdasarkan pengujian yang dilakukan pada daun Bandotan diperoleh kandungan senyawa fitokimia flavonoid,saponin,tanin, dan steroid.

Flavonoid terdeteksi pada daun bandotan ditandai dengan terbentuknya warna kuning pada penambahan larutan $\mathrm{NaOH}$ encer dan warna kuning akan hilang kembali apabila ditambahkan $\mathrm{HCl}$ encer. Keberadaan flavonoid dalam tumbuhan juga dinyatakan olek Waluyo (2013) bahwa flavonoid adalah kelompok senyawa polyphenol yang secara alami terdapat pada buah-buahan, sayuran, kacang-kacangan, biji, bunga, daun, kulit, 
pohon, dan lain-lain. Flavonoid termasuk salah satu klompok senyawa aromatik yang termasuk polifenol dan mengandung antioksidan. Flavonoid adalah senyawa yang terdiri dari 15 atom karbon yang umumnya tersebar didunia tumbuhan

Pengujian saponin pada daun bandotan dinyatakan positif walaupun busa yang dihasilkan sedikit. Saponin adalah jenis senyawa kimia yang berlimpah dalam berbagai spesies tumbuhan senyawa ini merupakan glikosida amfipatik yang dapat mengeluarkan busa jika dikocok dengan kencang didalam larutan dan busanya bersifat setabil tidak mudah hilang. Senyawa saponin terdeteksi pada bandotan. Saponin memiliki glikosil yang berfungsi sebagai gugus polar. Senyawa yang memiliki gugus polar dan nonpalar bersifat aktif permukaan sehingga saat dikocok dengan air, saponin dapat membentuk misel. Pada struktur misel gugus polar menghadap ke luar sedangkan gugus nonpolarnya menghadap ke dalam. Keadaan inilah yang tampak seperti busa, karena itu dalam analisis ini dilihat kemampuan sampel dalam membentuk busa (Sangi., dkk., 2008)

. Hasil analisis tanin terhadap ekstrak daun Bandotan dinyatakan positif mengandung tanin, ditandai dengan terbentuknya endapan kuning pada saat ekstrak sampel direaksikan dengan larutan $\mathrm{Pb}$ Asetat 1\%. Sekunder. Dalam dunia pengobatan, tanin dimanfaatkan untuk mengobati diare, menghentikan pendarahan, dan mengobati ambeien. (Noviyanty,dkk 2019).

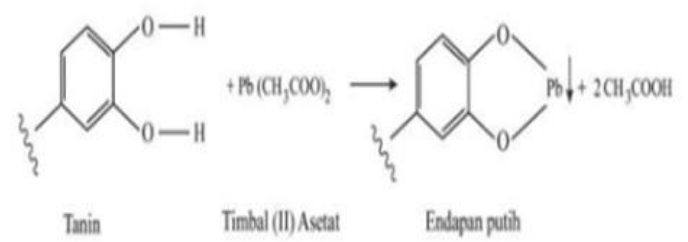

Gambar 1. Reaksi Tanin Dengan Pb Asetat

Pada Analisis analisis steroid dan terpenoid ini didasarkan pada kemampuan senyawa terpenoid dan steroid membentuk warna oleh $\mathrm{H}_{2} \mathrm{SO}_{4}$ pekat dalam pelarut anhidrida asam asetat Prinsip uji LiebermanBurchard untuk mengidentifikasi senyawa golongan steroid salah satunya adalah kolesterol. Pereaksi Lieberman Burchard merupakan campuran antara asam setat anhidrat dan asam sulfat pekat. Untuk mengekstraksi senyawa steroid termasuk kolesterol digunakan asam asetat anhidrat, memastikan media bebas air dan membentuk turunan asetil dari steroid. Warna hijau akan dihasilkan apabila larutan ditetesi asam sulfat pekat melewati dinding tabung untuk senyawa steroid termasuk kolesterol. Mekanisme yang terjadi dalam uji ini ketika asam sulfat ditambahkan ke dalam campuran yang berisi kolesterol, maka molekul air berpindah dari gugus C3 kolesterol, kolesterol kemudian teroksidasi membentuk 3,5-kolestadiena. Produk ini dikonversi menjadi polimer yang mengandung kromofor yang menghasilkan warna hijau. Terbentuknya warna hijau disebabkan karena adanya gugus hidroksi $(-\mathrm{OH})$ dari kolesterol bereaksi dengan pereaksi Lieberman Burchard dan meningkatkan konjugasi dari ikatan tak jenuh dalam cincin yang berdekatan. Reaksi antara kolesterol dari golongan steroid seperti pada gambar 3. (Sahriawati, dkk 2019).

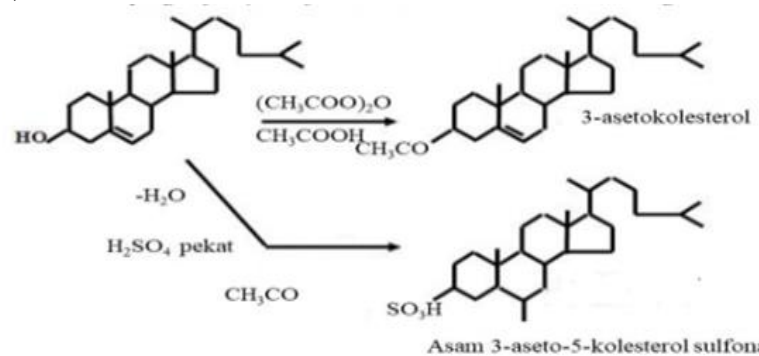

Gambar 2. Reaksi Senyawa Golongan Steroid Dengan Lieberman-Buchard (Sahriawati, dkk .2019)

\section{Aktivitas Antibakteri Escheresia coli}

Aktivitas antibakteri ekstrak daun bandotan terhadap Escheresia coli dapat dilihat pada Tabel 3.

Tabel 3. Penghambatan Bakteri Escheresia coli Ekstrak Daun Bandotan

\begin{tabular}{|c|c|c|c|c|c|c|}
\hline \multirow[b]{2}{*}{ Ulangan } & \multicolumn{6}{|c|}{ Diameter Zona Penghambatan (mm) } \\
\hline & $\begin{array}{c}\text { Chloram- } \\
\text { penicol } \\
10 \\
\mu \mathrm{g} / \text { well }\end{array}$ & Aceton & $\begin{array}{c}100 \\
\mu \mathrm{g} / \mathrm{well}\end{array}$ & $\begin{array}{c}200 \\
\mu \mathrm{g} / \mathrm{well}\end{array}$ & $\begin{array}{c}400 \\
\mu \mathrm{g} / \mathrm{well}\end{array}$ & $\begin{array}{c}600 \\
\mu \mathrm{g} / \mathrm{well}\end{array}$ \\
\hline 1 & 21,66 & 0 & 0 & 10,66 & 14,33 & 15,00 \\
\hline 2 & 23,00 & 0 & 0 & 8,67 & 9,33 & 9,33 \\
\hline 3 & 23,67 & 0 & 0 & 10,00 & 11,33 & 12,33 \\
\hline $\begin{array}{l}\text { Rata } \\
\text {-rata }\end{array}$ & 22,77 & 0 & 0 & 9,77 & 11,66 & 12,22 \\
\hline
\end{tabular}

D. Aktivitas Antibakteri Propionibacterium acnes

Aktivitas penghambatan bakteri Propionibacterium acnes pada daun bandotan (Ageratum conyzoides Lin) dapat dilihat pada tabel berikut.

Tabel 4. Penghambatan Bakteri Propionibacterium acnes dari Ekstrak Daun Bandotan

\begin{tabular}{ccccccc}
\hline & \multicolumn{5}{c}{ Diameter Zona Penghambatan (mm) } \\
\cline { 2 - 7 } Ulangan & $\begin{array}{c}\text { Chloram- } \\
\text { penicol } \\
10\end{array}$ & Aceton & $\begin{array}{c}100 \\
\mu \mathrm{g} / \mathrm{well}\end{array}$ & $\begin{array}{c}200 \\
\mu \mathrm{g} / \mathrm{well}\end{array}$ & $\begin{array}{c}400 \\
\mu \mathrm{g} / \mathrm{well}\end{array}$ & $\begin{array}{c}600 \\
\mu \mathrm{g} / \mathrm{well}\end{array}$ \\
\hline 1 & 32,66 & 0 & 11,00 & 11,00 & 12,00 & 13,00 \\
2 & 33,33 & 0 & 9,00 & 11,33 & 10,00 & 11,67 \\
3 & 34,00 & 0 & 8,33 & 11,66 & 10,00 & 15,33 \\
\hline Rata & 33,33 & 0 & 9,44 & 11,33 & 10,67 & 13,33 \\
-rata & & & & & & \\
\hline
\end{tabular}

E. Aktivitas Antibakteri Streptococcus sobrinus

Tabel 5. Penghambatan Bakteri S. sobrinus Ekstrak Daun Bandotan

\begin{tabular}{ccccccc}
\hline & \multicolumn{5}{c}{ Diameter Zona Penghambatan (mm) } \\
\cline { 2 - 7 } Ulangan & $\begin{array}{c}\text { Chloram- } \\
\text { penicol } \\
10\end{array}$ & Aceton & $\begin{array}{c}100 \\
\mu \mathrm{g} / \text { well }\end{array}$ & $\begin{array}{c}200 \\
\mu \mathrm{g} / \text { well }\end{array}$ & $\begin{array}{c}400 \\
\mu \mathrm{g} / \mathrm{well}\end{array}$ & $\begin{array}{c}600 \\
\mu \mathrm{g} / \text { well }\end{array}$ \\
\hline 1 & 30,67 & 0 & 10,00 & 9,33 & 11,66 & 16,00 \\
2 & 32,67 & 0 & 9,67 & 10,00 & 12,33 & 16,66 \\
3 & 34,67 & 0 & 9,33 & 12,00 & 12,66 & 18,00 \\
\hline Rata & 32,67 & 0 & 9,66 & 10,44 & 12,22 & 16,89 \\
-rata & 32,67 & & & & & \\
\hline
\end{tabular}




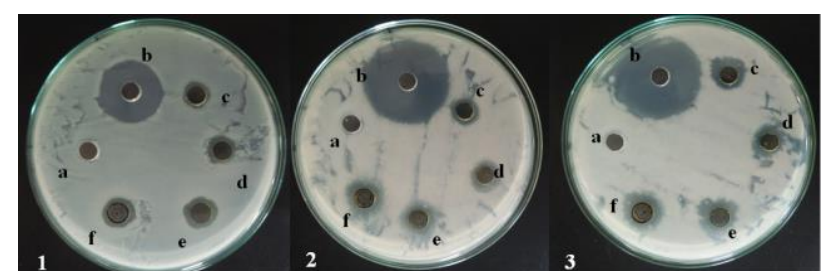

Gambar 3. Penghambatan Ekstrak Daun Bandotan terhadap 1. Escheresia coli, 2. Propionibacterium acnes, dan 3. Streptococcus sobrinus dengan a. aseton (kontrol negatif) dan b. Chlorampenicol (kontrol positif) pada konsentrasi $(\mu \mathrm{g} / \mathrm{well})$ c. 100 , d. 200 , e. 400 , dan f. 600

Pada Tabel 3, 4, dan 5 disampaikan bahwa nilai ratarata penghambatan bakteri dari ekstrak etanol daun bandotan pada konsentrasi $100 \mu \mathrm{g} / \mathrm{well}, 200 \mu \mathrm{g} / \mathrm{well}$, $400 \mu \mathrm{g} /$ well., dan $600 \mu \mathrm{g} /$ well. Hasil penelitian menunjukkan bahwa zona hambat menjadi lebih besar sejalan dengan semakin besar konsentrasi ekstrak. zona hambat pada konsentrasi $600 \mu \mathrm{g} /$ well menunjukkan penghambatan yang terbesar terhadap ketiga bakteri tersebut dibandingkan dengan konsentrasi lainnya. Perbedaan diameter zona hambat pada masing-masing konsentrasi diduga disebabkan oleh perbedaan besarnya senyawa aktif yang terkandung dalam masing-masing konsentrasi. Dalam konsentrasi yang lebih tinggi mengandung senyawa aktif yang lebih tinggi, begitu pula sebaliknya. (Lingga dkk. 2016).

Konsentrasi hambat minimum (KHM) pada bakteri E.coli yang disajikan pada tabel 4 yaitu antara 100-200 $\mu g$ /well, ini berbeda dengan bakteri $P$. acnes dan $S$. Sobrinus yang disajikan pada tabel 3 dan 5 KHM masingmasing pada konsentrasi di bawah $100 \mu \mathrm{g} /$ well. Hasil pengujian menunjukkan bacteri P.acnes dan S.sobrinus yang merupakan bakteri gram positif lebih rentan dibanding bakteri $E$. coli yang merupakan bakteri gram negatif. Hasil ini sejalan dengan pernyataan Breijyeh et al. (2020) bahwa bakteri memiliki sensitivitas yang berbeda terhadap agen antibakteri. Biasanya bakteri gram-positif lebih sensitif terhadap agen antibakteri dibandingkan dengan bakteri gram negatif. Bakteri gram negatif memiliki membran luar di dinding selnya yang tidak mudah ditembus atau dirusak oleh antibakteri tertentu.

Bakteri E. coli memiliki tiga lapisan dinding sel sehingga beberapa senyawa tidak mampu merusak jaringan dari dinding selnya. Demikian juga yang dinyatakan oleh Septiani dkk (2017) bahwa dinding sel bakteri gram negatif mengandung tiga polimer yaitu lapisan luar lipoprotein, lapisan tengah lipopolisakarida dan lapisan dalam peptidoglikan dan membran luar berupa bilayer (mempunyai ketahanan lebih baik terhadap senyawa - senyawa yang keluar atau masuk sel dan menyebabkan efek toksik)

\section{KESIMPULAN}

Ekstrak etanol daun bandotan terdeteksi senyawa metabolit sekunder yaitu dari golongan flavonoid, saponin, tannin, dan steroid, senyawa yang tidak terdeteksi yaitu Alkaloid dan terpenoid. Eksrak etanol daun bandotan berpotensi sebagai bahan antibakteri dengan KHM pada E. coli antara 100-200 $\mu \mathrm{g} /$ well dan pada P. acne dan S. Sobrinus di bawah $100 \mu \mathrm{g} /$ well.

\section{DAFTAR PUSTAKA}

Deasywati. 2011. Aktivitas Antimikroba Dan Identifikasi komponen Aktif Rimpang Temulawak (Curcuma Xanthorrhiza roxb). Universitas Indonesia. Depok.

Harborne, J.B., (1987), Metode Fitokimia, Edisi ke dua, ITB, Bandung

Hidayah. N, Hisan. A. K, Solikin. A, Irawati, Mustikaningtyas. D, Uji Efektivitas Ekstrak Sargassum muticum Sebagai Alternatif Obat Bisul Akibat Aktivitas Staphylococcus aureus

Kurniawan. E, Jekti. D. S. D., Zulkifli. L. (2019). Aktivitas Antibakteri Ekstrak Metanol Batang Bidara Laut (Strychnos ligustrina) Terhadap Bakteri Patogen, Jurnal Biologi Tropis.

Kusnadi, Devi. E. T. (2017). Isolasi dan Identifikasi Senyawa Flavonoid Pada Ekstrak Daun (Apium graveolens L.) Dengan Metode Refluks. Pancasakti Science Education Journal

Kokate. (2001). Pharmacohnosy. 16th ed. India; Nirali Prakasham

Lingga, A. R., Pato, U., \& Rossy, E. (2016) Uji antibakteri ekstrak batang Kecombrang (Nicolaia speciosa Horan) terhadap Staphylococcus aureus dan Escherichia coli. JOM Faperta, 3(1)

Marliana, S. D., Saleh, C. (2011). Uji Fitokimia dan Aktivitas Antibakteri Ekstrak Kasar Etanol, Fraksi nHeksana, Etil asetat, dan Metanol dari Buah Labu Air (Lagenari Siceraria (Morliana). J. Kimia Mulawarman

Mengkido. M, Lambui. O, Harso. W, (2019) Uji Daya Hambat Ekstrak Daun Bandotan (Ageratum conyzoides L.) Terhadap Pertumbuhan Bakteri Staphyllococcus Aureus., Biocelebes.13(2)

Noviyanti.Y, Hepiyansori, Agustian, (2019). Identifikasi Dan Penetapan Kadar Senyawa Tanin Pada Ekstrak Daun Biduri (Calotropis gigantea) Metode SpektrofotometerUV-VIS, Jurnal Ilmiah Manuntung. 6(1)

Sahriawati, Sumarlin, Wahyuni. S,(2019). Validasi Metode dan Penetapan Kadar Kolesterol Ayam Broiler dengan Metode Lieberman- Burchard. Lutjanus.

Sangi. M, Runtuwene. M. R. J. , Simbala. H. E. I. dan Veronica M. A. (2008). Analisis Fitokimia Tumbuhan Obat Di Kabupaten Minahasa Utara, Chem. Prog. 1(1)

Septiani, Dewi. E. N., Wijayanti. I. (2017). Aktivutas Antibakteri Ekstrak Lamun (Cymodocea rotundata) 
Buletin Poltanesa Vol. 22 No. 2 (Desember 2021) p-ISSN 2721-5350 e-ISSN 2721-5369

https://doi.org/10.51967/tanesa.v22i2.891 @ 2021 Politeknik Pertanian Negeri Samarinda

This work is licensed under a Creative Commons Attribution-ShareAlike 4.0 License

Terhadap BakteriI Staphylococcus aureus Dan

Escherichia coli. Saintek Perikanan. 13(1)

Waluyo. T. K, Pasaribu. G, (2013). Aktivitas Antioksidan dan Antikoagulasi Resin Jernang, Jurnal Penelitian Hasil Hutan 31(4)

Xia. E. Q, Deng. G. F, Guo. Y. J, Li. H. B,(2010) Biological Activities of Polyphenols from Grapes. Int.J.Mol.Sci. 